\title{
"CC" e a patologização do natural: higiene, publicidade e modernização no Brasil do pós-Segunda Guerra Mundial
}

\section{Elizabete Kobayashi ${ }^{1}$ Gilberto Hochman'}

RESUMO: O objetivo do artigo é discutir a relação entre consumo e mudança de hábitos por meio de novos produtos industrializados relacionados à saúde e à higiene, que foram anunciados como capazes de substituir o odor natural pelo cheiro artificial e industrializado. Sugerimos que foi um processo social e cultural de transformação de funções fisiológicas naturais, como o suor e o mau hálito, em algo nocivo à saúde e repugnante socialmente e também em um sinônimo de atraso. $\bigcirc$ ideal de uma vida higiênica, moderna e desodorizada encontrou na imprensa e na publicidade - em processo de modernização e expansão no Brasil após a Segunda Guerra Mundial - o espaço privilegiado para a veiculação e oferta de novos e abundantes produtos que prometiam cancelar a ameaça do "cheiro de corpo", o "CC", e substituí-lo pelo "cheiro bom", salubre e socialmente aceitável que poderia, inclusive, ser comprado.

PALAVRAS-CHAVE: Consumo. Higiene. Imprensa. Cheiro de corpo. Modernização.

ABSTRACT: The aim of this article is to discuss the relationship between consumption and changing habits through new industrial products related to health and hygiene, which were announced as the possibility of replacing the natural odor and industrialized by artificial smell. This would represent the cultural transformation of natural physiological functions, such as sweat, something unwholesome and socially repugnant and also a synonym for backwardness. The ideal of a hygienic, modern and deodorized find life in the media and advertising - in the modernization and expansion process in the Brazil post-ll World War the privileged space for the placement and supply of new and abundant products that promised to cancel the threat of "body odor" - "BO" and replace it, by the "smell good", hygienic and socially enjoyable that could be bought.

KEYWORDS: Consumption. Hygiene. Press. Body odor. Modernization.
1. Pós-doutoranda no Programa de Pós Graduação em Ciência, Tecnologia e Sociedade da Universidade Federal de São Carlos (PPGCTS-UFSCar). E-mail: < betekobayashi@yahoo.com. br>.

2. Pesquisador e Professor do Programa de PósGraduação em História das Ciências e da Saúde, Casa de Oswaldo Cruz Fundação Oswaldo Cruz (COC-Fiocruz). E-mail: <gilberto.hochman@gmail. com>. 
3. Cf. O Cruzeiro $(09 / 02 / 1957$, n. 17, p. 125).
Introdução

No período compreendido entre a segunda metade dos anos 1940 até a primeira metade dos 1960, o Brasil experimentou a consolidação de um mercado de bens de consumo e de um parque industrial que se mesclou à experiência democrática do período. Esse mercado consumidor vinha se constituindo desde o início do século XX. Contudo, no período em questão, este processo acelera-se, com o adensamento de uma classe média urbana, com a modernização da imprensa e da publicidade no Brasil - dinâmicas sob a égide da ideia de desenvolvimento. Esses novos bens materiais e simbólicos traduziam, também, a aspiração à modernidade e ao progresso desses setores urbanos e da própria elite política.

objetivo deste artigo é discutir a relação entre consumo e mudança de hábitos a partir de novos e variados produtos relacionados à saúde e à higiene, propagandeados como capazes de substituir o natural pelo artificial, pelo fabricado. Isso representou a celebração de novos hábitos de higiene e de consumo que deveriam ser buscados pela sociedade brasileira; um processo no qual a publicidade desempenhou um papel central de difusão e oferta dessa nova maneira, moderna e saudável, de se viver. Para que a compra e o consumo se efetivassem, os anúncios comunicavam questões para além da funcionalidade objetiva dos produtos. Comprava-se um aspirador de pó para que se mantivesse a casa livre da sujeira e, principalmente, das doenças. A geladeira era sinônimo de status para sua proprietária e, ao mesmo tempo, saúde para a família, iá que os alimentos passariam a ser conservados de uma maneira mais adequada. $\bigcirc$ sabonete garantiria proteção higiênica e eliminação dos maus odores do corpo e, com isso, mais e melhores relacionamentos amorosos, fraternos e sociais.

A publicidade buscava persuadir o consumidor de que essas aquisições representariam um investimento na vida pessoal, na manutenção da saúde e no bemestar da família. Ao mesmo tempo, esses anúncios representavam para a imprensa que os veiculava uma fonte de renda importante que garantiria a manutenção da publicação dos jornais e periódicos. Esse circuito econômico também era apresentado pelos veículos da imprensa como a sua contribuição ao desenvolvimento do país. Por exemplo: a revista $\bigcirc$ Cruzeiro anunciou que teria ajudado "o Comércio e a Indústria do país a venderem Cr\$4.500.000.000,00, em 1955"3.

consumo foi apresentado como uma via de acesso a uma nova maneira de viver, mais prática, mais higiênica, menos braçal, mais mecanizada e mais racional. Tudo isso poderia ser adquirido. Isso traduziu-se explicitamente em muitos produtos, e neles saúde, modernidade e consumo entrelaçavam-se. Um bom exemplo dessa aliança entre saúde e novos hábitos de consumo pode ser identificada nos anúncios de lenços de papel. A recomendação era não guardar o resfriado na bolsa. O lenço de papel, descartável, além de se proclamar mais higiênico, prometia evitar a proliferação dos germes e das doenças. $\bigcirc$ apelo era que se substituísse o então velho lenço de pano pelo descartável. $\bigcirc$ primeiro representava o atraso e a doença. $\bigcirc$ segundo seria uma 
novidade da indústria que portava o moderno, a praticidade e, fundamentalmente, a saúde.

A aquisição e o consumo desses novos produtos representavam mais do que as suas características físicas. Era sinônimo de que o tradicional, agora associado ao atraso, seria superado pelo consumo e, principalmente, de que o caseiro e o natural seriam substituídos - definitivamente - pelo industrial. Tratava-se da adoção de novos hábitos de higiene e de saúde por intermédio do mercado. Nesse contexto, até mesmo o "cheiro de corpo", o "CC", foi alvo de uma campanha publicitária. $\bigcirc$ "CC" - até então algo natural, e sem um rótulo ou denominação - transformou-se em uma patologia, em uma espécie de doença, que deveria e poderia ser combatida com a aquisição de um produto. Foi certamente um episódio relevante de um processo mais longo de construção de uma sensibilidade moderna que catalogou os odores em termos de lugares, grupos sociais, e partes do corpo, num gradiente entre repulsa e valorização.

Ainda que a propaganda de produtos de higiene e de limpeza oferecesse a possibilidade de comprar saúde embalada nas décadas de 1920 e 1930, a novidade do período do pós-guerra, em particular no Brasil, foi a aceleração no processo, tanto de produção desses produtos como de sua divulgação nos meios de comunicação, em especial em revistas ilustradas semanais. Houve uma associação inédita entre o processo de urbanização, de industrialização e da modernização da imprensa e da publicidade. Isso aplicava-se também ao olfato do brasileiro, que nesse período (especialmente de 1920 a 1960) seria sistematicamente educado a repudiar odores naturais.

$\bigcirc$ ato de cheirar, aparentemente inato, é, para Alain Corbin ${ }^{4}$, uma ação condicionada, educada a tolerar ou a repugnar certos odores. Além do aspecto puramente fisiológico, cheirar é um ato permeado de interferências sociais, culturais e sexuais: "Cheirar não é simplesmente um fenômeno biológico ou psicológico. Cheirar é algo cultural, portanto, um fenômeno histórico e social"5.

$\bigcirc$ corpo, propriamente dito, apresentou diferentes significações ao longo do tempo. No século XIX, ele expressaria a personalidade por meio da exploração de suas "sensações viscerais", quando se buscava revelar as impressões que se manifestavam no "diafragma, no estômago ou no abdômen". No século $X X$, o corpo transformou-se em algo percebido como mais complexo. Não seria apenas um emissor de meras sensações, mas a representação de uma imagem que se torna parte integrante "de um eu que não pode pensar sem o corpo". Esse corpo passa a ser reflexivo, fonte de eventos, local de ideias e de afetos, uma valorização do corpo e do gosto por sib. A beleza se tornaria um bem acessível a todos no século XX. E essa beleza traduziu-se nas possibilidades dos produtos de beleza e também na atitude em relação a si mesmo, com a prática de exercícios físicos, por exemplo. O mais importante era "esse tal poder atribuído à vontade, é essa tal promoção da vigilância e da escuta do eu"7.

No caso da eliminação do cheiro de corpo, a solução foi oferecida em formato de sabonete capaz de resolver um novo problema: o odor corpóreo que
4. Ver Alain Corbin (1987, p. 10).

5. Cf. Constance Classen; David Howes e Anthony Synnott (2002, p. 3). Todas as traduções são dos autores.

6. Cf. Georges Vigarello (2014).

7. Cf. Id. (2005, p. 245). 
8. O sabão de cinzas era um preparado caseiro, elaborado a partir de uma lixívia de cinzas de madeira misturada a grandes quantidades de gordura animal, sob aquecimento. O sabão era utilizado no uso da higiene do corpo, das roupas e dos utensílios da cozinha e das casas. Ver Paulo César Pinheiro e Marcelo Giordan (2010).

9. O lançamento da revista $O$ Cruzeiro em 1928 foi um exemplo do grande desenvolvimento da imprensa brasileira da década de 1930, consolidando a estrutura empresarial no que se refere ao fazer jornalístico. No caso de O Cruzeiro, o lançamento foi precedido de uma intensa campanha publicitária. Fundada por Carlos Malheiros Dias, a publicação integrou o grupo de Assis Chateaubriand, passando a circular nacionalmente, no que foi pioneira Ver Nélson Werneck Sodré (1977, p. 428). Durante seus quarenta e sete anos de existência a revista circulou semanalmente de maneira quase ininterrupta. Lançada como Cruzeiro, passou a adotar o artigo "O" em seu título, na edição número 31 , de 08 de junho de 1929. A imprensa continuou nesse ritmo de concentração dos meios (jornais, revistas, rádios e televisão) nas décadas seguintes de 1940 e 1950. Exemplo disso é o conglomerado Diários Associados do mesmo Chateaubriand. Essa concentração decretou o falecimento de muitos jornais e revistas, com o aparecimento de poucos novos títulos. A revista $O$ Cruzeiro continuou a circular, incorporada pelos Diários Associados. Apenas uma grande revista foi concorrente à altura de $O$ Cruzeiro nessa fase de concentração, a Manchete. Ver Ibid. (p, 446).

10. Adolpho Bloch fora transformado em algo abjeto. Embora o sabão ou o sabonete de cinzas ${ }^{8}$ já estivesse incorporado no cotidiano dos lares, a novidade estava na substituição do natural, agora repugnante, por um aroma industrializado, agradável. $\bigcirc$ sabonete industrializado era oferecido como eficaz, ao alcance do consumidor na solução do problema do "CC".

No combate aos odores corporais, a preocupação dividiu-se entre os diferentes sabonetes, os enxaguatórios bucais, as pastas dentais e os desodorantes para cancelar os cheiros emanados do corpo e substituílos pelos odores agradáveis. Para a publicidade, os indivíduos poderiam não apenas trocar o "CC" e o "bafo" pelo corpo perfumado e o bom hálito, mas escolher entre vários odores, produtos e marcas. Quaisquer que fossem os problemas, a publicidade ofereceria um produto que prometia ser capaz de resolvê-lo, especialmente naquilo que se relacionasse à manutenção de um corpo saudável e, sobretudo, perfumado e desodorizado.

A discussão em torno da aquisição de novos hábitos de higiene e de consumo faz com que se empreenda uma análise sobre o significado do consumo nesse período e a representação das duas maiores revistas de circulação semanal e nacional da época analisada: $O$ Cruzeiro $^{9}$ e Manchete $^{10}$. A primeira parte do artigo aborda a questão do incentivo ao consumo como uma possibilidade de se adquirir produtos que transformariam a vida cotidiana em algo mais higiênico e mais racional. A segunda e a terceira parte analisam os anúncios veiculados nessas revistas, enfatizando a eliminação do "cheiro de corpo" ou a adoção do odor industrializado em detrimento do natural. Ao final, conclui-se sobre as relações entre higiene, consumo e modernização no Brasil das duas décadas após a II Guerra Mundial.

Vendendo saúde: além da materialidade do produto

A difusão da praticidade e de uma sensação do poder de compra pode ser considerada um traço da cultura de consumo que se consolidou a partir do final da Segunda Guerra Mundial. Em consonância com esse contexto, a imprensa leia-se jornalismo e publicidade - também consolidou seu processo de profissionalização e modernização. A aquisição de novas máquinas capazes de imprimir exemplares de jornais e revistas em volume e qualidade maiores propiciou um campo fecundo para a publicidade no Brasil. Na década de 1950, a publicidade brasileira, inspirada nas agências americanas que aqui estavam desde o final dos anos 1930, passou a investir em anúncios elaborados por profissionais da área. Os textos e as imagens procuravam valorizar a adoção dos novos produtos como uma maneira de se adquirir benefícios que extrapolavam sua utilidade imediata.

Esse incentivo ao consumo também pode ser considerado um traço novo no contexto do pós-guerra. Segundo Peter Stearns, uma das marcas das sociedades pré-modernas era justamente o oposto: "A mais óbvia característica do tradicional 
não-consumo envolvia a amplitude da pobreza: a maioria das pessoas não possuía o suficiente para se engajar num consumo substancial" ${ }^{\prime 1}$. Outros pontos, tais como a religião e o bem público, acabavam inibindo o desejo de consumir. Segundo o autor, limitações ao consumo - pobreza, hierarquia e condenação ao consumismo - ainda continuavam presentes nas sociedades modernas, mas isso declinou fortemente graças ao aumento do entusiasmo em torno do consumo e de seus significados ${ }^{12}$.

Para Stearns, já era da natureza humana "estar aberto a se deliciar com a aquisição de novos bens" ${ }^{13}$, mesmo que não se tratasse de suprir as necessidades básicas. Somava-se a isso o atrativo das novas mercadorias e os métodos de marketing [e propaganda] que possibilitavam novas maneiras de estimular os indivíduos a gastar seus rendimentos. Dessa forma, segundo Stearns, "o resultado estaria assegurado: o consumo iria emergir e crescer" ${ }^{14}$. Conforme o autor, o consumo desenvolveu-se num contexto onde os novos bens e métodos comerciais estavam em cena, e também onde o dinheiro estava disponível para um grupo maior de indivíduos ${ }^{15}$.

Entre as décadas de 1940 e 1960, veiculava-se que pelo consumo seria possível alcançar diferentes soluções para questões do cotidiano, como exterminar os parasitas e insetos das residências. Charles McGovern destaca que os publicitários norte-americanos caracterizavam o passado como um tempo em que não se podia contar com os modernos produtos: "os bens materiais do presente seriam soluções para os 'problemas' do passado"16. No Brasil, a publicidade também adotou esse argumento. Isso explica-se pela presença de grandes agências norte-americanas como a J. Walter Thompson, Mc-Cann Erickson, entre outras, que chegaram ao país, na década de 1930, mesmo período em que essa visão sobre o passado era difundida nos Estados Unidos.

Daniel Miller explica que a definição do termo "consumo" não pode ser reduzida ao simples ato de comprar. Segundo ele, "é essencial destacar que o conceito inclui a recepção dos serviços prestados pelo estado, bem como os produtos do mercado"17. $\bigcirc$ autor indica também que o ato de consumir não se restringe a uma atividade individual. $\bigcirc$ consumo pode ser considerado, para Miller, como um ato público realizado em grupo, ou uma apropriação estatal realizada por meio das importações. Já o consumo de produtos do dia a dia relaciona-se mais como a "moral econômica" do mundo doméstico do que com um ato individual ${ }^{18}$.

Para nosso argumento, foi na esfera doméstica e no ato de compra das donas de casa, de meados do século passado, que o consumo de higiene se efetivou. Esse argumento é inspirado em Miller e também na ideia de "dimensão privada da higiene pública"19 de Nancy Tomes ao analisar a incorporação da bacteriologia e da higiene moderna nos lares dos Estados Unidos na virada do século XIX para o XX. Da mesma maneira, como proposto por Miller, não se tratava de um ato isolado ou individual, mas de uma atividade guiada por valores como cuidado com a família, com os filhos e, principalmente, com a higiene, a saúde e a economia do lar. apresentou em 1951 um projeto de criação de uma revista a Henrique Pongetti e Raimundo Magalhães Júnior, "amigos intelectuais", e a seu primo Pedro Bloch. Adolpho acreditava que havia espaço no mercado editorial brasileiro para o lançamento de mais uma revista semanal de variedades. Com base na experiência obtida na antiga URSS, nas tipografias da família e no Rio de Janeiro, Adolpho "alicerçava-se nas possibilidades de introduzir inovações editoriais na publicação e aprimoramentos técnicos no equipamento gráfico para vencer o desafio de concorrer com $O$ Cruzeiro". No início, as primeiras edições eram "rodadas" nas tipografias da família, a um baixo custo e com uma capacidade de imprimir 200 mil exemplares semanalmente. Mesmo assim, a Manchete foi lançada com o mesmo valor de venda de O Cruzeiro. Cf. Ana M.R de Andrade e José L.R. Cardoso (2001, p. 250). Andrade e Cardoso enfatizam o sucesso da empresa Bloch, que em poucos anos conseguiu se instalar em uma sede própria na Rua Frei Caneca, Lapa, próxima aos importantes jornais e também de sua concorrente. Adquiriram-se máquinas capazes de rodar $800 \mathrm{mil}$ exemplares por semana, produzidos num parque gráfico construído no subúrbio do Rio de Janeiro. Os autores destacam que, utilizando-se de uma estratégia contrária à de $O$ Cruzeiro, a Manchete não declarava sua tiragem. Além da excelência na produção técnica da revista, o corpo editorial contava com profissionais egressos da própria $O$ Cruzeiro, e também com nomes como Orígenes Lessa, Carlos Drummond de Andrade, Joel Silveira, Rubem Braga, Nélson Rodrigues, Manuel Bandeira, entre outros nomes importantes da intelectualidade brasileira. 
11. Cf. Peter N. Stearns (2006, p. 1).

12. Ver Ibid. (p.2).

13. Cf. Ibid. (p.29).

14. Cf. Ibid. (p. 29).

15. Ver Ibid. (p.30)

16. Cf. Charles F. McGovern (2006, p. 266).

17. Cf. Daniel Miller (1995, p. 31).

18. Cf. Ibid., loc.cit.

19. Cf. Nancy Tomes (1999).
No Brasil de meados do século XX, os anúncios ofereciam muitos produtos diversificados. As vendas a prazo, facilitadas pelo crediário, acenavam com a possibilidade de se adquirir todas essas facilidades modernas e com isso alcançar metas, redefinidas, de saúde, conforto, limpeza, beleza e estabilidade individual e familiar. Neste artigo, utilizamos os anúncios publicados na revista $O$ Cruzeiro e Manchete, como fontes de pesquisa e de análise.

A eliminação do "CC": o cheiro bom como um bem material

Cabe analisar a oferta de produtos de higiene pessoal que prometiam eliminar uma nova ameaça: o "cheiro de corpo" - "CC". Em séculos anteriores exalar seu próprio cheiro era algo natural, assim como os próprios odores oriundos de locais considerados, potencialmente, fétidos, como a axila, a boca e o corpo de maneira geral. Todavia, em meados do século XX, exalar um cheiro natural do corpo tornara-se sinônimo de falta de higiene e de atraso. A campanha publicitária do sabonete Lifebuoy promovia explicitamente o combate ao "CC" iá nos anos 1940. O anúncio era categórico:

Nada de 'C.C.' (cheiro de corpo) comigo... - Uso Lifebuoy. Sua garantia está no odor puro e refrescante de Lifebuoy. Lifebuoy contém o elemento especial que de fato evita o 'C.C.' $E$, embora seu odor DESAPARECA quase instantaneamente, a ação protetora de Lifebuoy se prolonga por muitas horas. Você sentirá em todo o corpo uma agradável sensação de frescor, a dar-the a certeza de que sua pele, deliciosamente limpa e macia, está mais resguardada e encantadora do que nunca. Lifebuoy é um grande sabonete. (Figura 1).

O cheiro defendido pelo anúncio do sabonete Lifebuoy, acima, possuía duas dimensões. A primeira, inerente ao produto: o extermínio do "cheiro de corpo" - "C.C." - e a promessa de uma pele limpa e macia, livre de seu odor natural. A outra se referia ao próprio aroma do produto. O sabonete Lifebuoy diferenciava-se de outros sabonetes pela defesa da saúde e por seu cheiro nada agradável, de desinfetante. $\bigcirc$ objetivo do produto não era ser perfumado, mas exterminar o "cheiro de corpo". Afinal, o que era pior: cheirar a "C.C." ou utilizar um sabonete com cheiro desagradável, mas que, como prometia o anúncio, desapareceria em pouco tempo? E mais: o odor de desinfetante do sabonete poderia conferir-the características de um remédio, capaz de curar o mau odor exalado pelo corpo.

Entre os diferentes produtos e marcas, destacamos os anúncios do sabonete Lifebuoy, analisando sua trajetória desde a autoproclamação de combate ao "C.C." até se tornar um produto bactericida que prometia proteger a saúde da família. Ao mesmo tempo, analisamos outros anúncios de diferentes marcas buscando comparar os diferentes discursos em torno da substituição do natural pelo artificial. Outro produto também levado em consideração é o desodorante. Com o silenciamento em torno do "CC", esses produtos tomaram para si a missão de exterminar o "mau hálito das axilas". Os anúncios deste e de outros produtos 


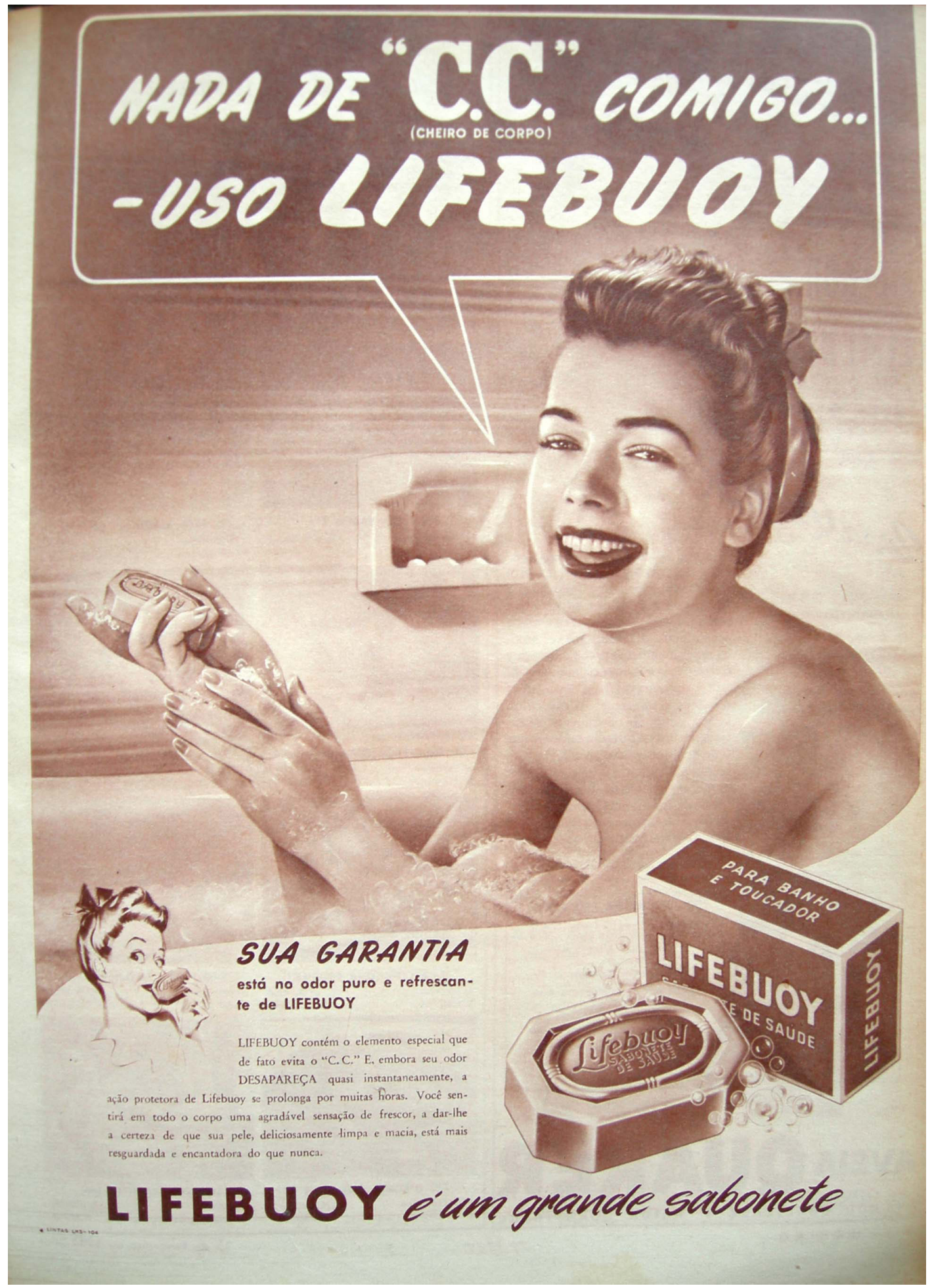

Figura 1 - Anúncio do sabonete Lifebuoy. O Cruzeiro, 15/02/1947, n. 17, p. 33. Acervo Biblioteca Nacional - Rio de Janeiro e Acervo Estado de Minas/Revista O Cruzeiro - Belo Horizonte. 
20. Embora o sabonete tenha sido lançado em 1937 , foi a partir da década de 1940, especialmente após o término da Segunda Guerra Mundial, que a campanha publicitária se intensificaria e alcançaria uma repercussão maior.

21. Na linguagem publicitária, o jingle é uma "mensagem musicada". Com a expansão do rádio no Brasil da década de 1930, foi um tipo de anúncio bastante utilizado na divulgação de produtos e serviços. No mesmo período, as rádios ainda veiculavam propagandas em que o próprio locutor improvisava a mensagem ou, simplesmente, lia textos preparados para veículos impressos sem qualquer tipo de adaptação para o meio radiofônico. Havia também uma forma mais profissionalizada, onde um redator elaborava textos adequados à linguagem do rádio, lidos pelos locutores das emissoras. Outra maneira de veicular os anúncios eram os spots, um texto de locução gravado previamente. Em 1936, a Unilever (resultado da junção da empresa holandesa Margarine Unie e a Lever Brothers, da Inglaterra) se esforçaria em conquistar o mercado brasileiro. Os jingles serviram como uma estratégia, não somente da Unilever, mas também de outras empresas internacionais, para conquistar um mercado urbano brasileiro que se começava a assumir uma postura consumista. Ver Roberto Simões (SIMÕES, 1990 , p. 171-180).

22. "Quando chega o verão/e aperta o calor/ transpira-se tanto/ que é mesmo um horror./ Para então se manter o asseio corporal/ é preciso se usar/ o sabonete batatal:/É mesmo o tal/ não tem rival./ É um herói/ Lifebuoy, Lifebuoy". serviram-nos de fontes para discutir a questão da necessidade do extermínio do mau cheiro exalado pelo corpo. Feito que, conforme essas mesmas fontes, só era possivel graças ao advento de produtos oriundos das indústrias químicas, farmacêuticas e cosméticas.

Lançada pela Unilever, no Brasil, a campanha do sabonete Lifebuoy começou a ser veiculada em $1937^{20}$ nas rádios brasileiras com o jingle 21 . "Este é o tal que não usa Lifebuoy", de autoria do publicitário Rodolfo Lima Martensen 22. Em seu livro de memórias, esse publicitário relatava que a ideia era demonstrar que o odor da transpiração afastava os amigos e as mulheres, e transformava o "tal' num renegado, num marginalizado pelo próprio corpo"23.

mesmo Martensen foi o criador do termo "C.C." - "cheiro de corpo" -, que ainda hoje é utilizado como sinônimo de mau cheiro. Na ocasião do lançamento do sabonete, Martensen traduziu, literalmente, a expressão body odor - "B.O." -, das campanhas nos países de língua inglesa. A incorporação do verbete "Cê-cê - s. m. - cheiro de corpo, fedor de suor; cê-cê" ao Dicionário Houaiss da Língua Portuguesa, pode ser considerada um indicador de que a preocupação com os odores naturais ainda se faz presente e de que a campanha conseguira ganhar a atenção dos potenciais consumidores.

Martensen fora contratado para reabrir a agência de publicidade Lintas $^{24}$ e promover a marca Unilever no país. Os executivos da Unilever no Brasil identificaram dois pontos que deveriam ser trabalhados. Um era o fato de considerar o brasileiro um "povo essencialmente limpo"25. $\bigcirc$ segundo argumento era de que, em 1937, o desodorante ainda não era um produto acessível a todos. Dessa maneira, a Unilever oferecia a solução a um baixo custo por meio de um produto acessível. Ao mesmo tempo, não precisou investir em outra mudança de hábito, o uso do desodorante, produto até então não incorporado no cotidiano do brasileiro. Nesse primeiro momento de campanha no Brasil, a finalidade do Lifebuoy era ser um sabonete desodorizante e desinfetante, especialmente para aqueles que não podiam (e nem pensavam em) comprar um desodorante.

Martensen relembrava ainda que a escolha de um brasileiro para o comando da campanha para vender sabonete a uma população considerada asseada pelos estrangeiros teria sido uma estratégia acertada da Unilever. Apesar dessa visão positiva do publicitário escolhido para desenvolver a campanha, outros profissionais, como o publicitário Edeson Ernesto Coelho, classificou a estratégia da campanha contra o "C.C." como o "maior desastre publicitário brasileiro": "ninguém queria comprar Lifebuoy, ninguém encarava. (...) $\bigcirc$ sujeito não podia entrar (...) e falar: 'Me dá um Lifebuoy'. Todo mundo olhava, se afastava, tinha gozação etc." 26 . Ao colocarmos de lado a discussão publicitária sobre o fracasso ou sucesso da campanha, o fato é que essa lembrança de Coelho evidencia o temor existente em relação ao "cheiro de corpo". Comprar o produto era encarado como uma confissão de fedor. Mesmo que se afirmasse: "Nada de 'C.C.' comigo... Uso Lifebuoy"27, a suspeita instalava-se. Ninguém queria ser condenado por exalar um cheiro desagradável. Ainda mais que no mercado de bens de consumo da 
década de 1950, o bom cheiro poderia ser adquirido por meio de diferentes produtos que garantiriam a ocultação/eliminação do "CC" e também prestígio e sucesso pessoal. Em alguns casos, diriam os anúncios, os maus odores causariam até mesmo fracasso profissional.

Esses posicionamentos em relação à compra do sabonete Lifebuoy denotam a ambiguidade do produto. Adquiri-lo poderia ser considerado como uma confissão de seus próprios fedores. Ao mesmo tempo, se não se corresse o risco de ser apontado como "malcheiroso", sem o sabonete o "CC" permaneceria. A dubiedade do produto ilustra o próprio empenho da publicidade em transformar potenciais consumidores em compradores de fato, ao tentar convencê-los a substituir o uso de produtos caseiros, tais como o sabão de cinzas ou o banho de cheiro preparado com ervas aromáticas.

Classen, Howes e Synnott consideram o apelo contra o "cheiro de corpo" como estratégia perfeita para uma campanha de marketing que se baseava em "medos anônimos" [nameless fears]: "os indivíduos não percebiam seu próprio cheiro, também não conseguiam visualizá-lo no espelho, nem mesmo os amigos mais próximos poderiam mencionar esse mau odor" 28 .

Dessa forma, a campanha do Lifebuoy também inaugurou, no Brasil, a possibilidade de se abordar o tema abertamente, desafiando esses "medos anônimos" apontados por Classsen, Howes e Synnott ${ }^{29}$. Ao longo das décadas de 1940 e 1950, a estratégia da campanha deslocou-se da defesa explícita do combate ao "CC" e se voltou para a valorização do perfume do Lifebuoy. A eliminação do termo "CC" das campanhas do Lifebuoy cedeu lugar a uma "perfumada proteção por muitas horas". Esse silenciamento em relação ao termo apresentava um sabonete capaz de eliminar o cheiro lantes mesmo de seu aparecimento): "... o novo Lifebuoy elimina o odor da transpiração antes mesmo que ele apareça!"30.

A utilização explícita do cê-cê foi substituída pela presença prolongada do perfume do sabonete e da prevenção contra o odor da transpiração. Essa estratégia parece confirmar o que Coelho criticara sobre a negatividade da campanha em que se pregava a eliminação do "C.C.". Isso não significa que o temor em relação ao mau cheiro de corpo tenha desaparecido dos argumentos dos anúncios. $\bigcirc$ oferecimento de uma "perfumada proteção por muitas horas" 31 ou de eliminar o "odor da transpiração antes mesmo que ele apareça"32, trazia implícita a ideia do mau cheiro.

A campanha publicitária indicava também a possibilidade de se adquirir saúde por meio de um produto, que ultrapassaria sua função básica de limpeza. $\bigcirc$ sabonete, fabricado "cientificamente", garantiria também saúde. $\bigcirc$ elemento purificador responsável pelo bom cheiro do sabonete e pelo combate ao odor do suor, também colaborava na manutenção da saúde das crianças e das famílias, e no combate aos micróbios. "Cuidado com o perigo das impurezas. Na poeira, no chão, em tôda parte! Só o sabonete Lifebuoy possui o ingrediente purificador que protege a saúde" 33 . $\bigcirc$ combate ao perigo da sujeira e dos germes também foi
O jingle foi adaptado para ser veiculado também no inverno: "Tanto faz no verão/ como no inverno t a m bém,/ noss a transpiração/ quase um litro contém./ Para então se manter o Asseio Corporal é preciso se usar um sabonete batatal./ É mesmo tal, não tem rival, é um herói: Lifebuoy, Lifebuoy!" Cf. Roberto Simões (1990, p. 181) e Rodolfo Lima Martensen (1983, p. 235).

23. Cf. Rodolfo L. Martensen (1983, p. 234)

24. A Lintas era a junção das siglas de Lever International Advertising System e atuava como uma agência de publicidade que cuidava exclusivamente da marca Unilever, em linguagem publicitária tratava-se de uma house agency. Em 1933, segundo as memórias de Martensen, a Lintas brasileira foi extinta por não existir condições de funcionamento de acordo com os padrões da Unilever. Em 1939, o brasileiro assumiria a reabertura da agência. Ver Rodolfo Martensen (1983, p. 228).

25. Cf. Rodolfo Martensen (1983, p. 233).

26. Cf. Edeson Ernesto Coelho (2005, p. 14).

27. Cf. O Cruzeiro $(15 / 02 / 1947$, n. 17 , p. 33$)$.

28. Cf. Constance Classen; David Howes e Anthony Synnott (2002, p. 183). Tradução dos autores.

29. Cf. Ibid., loc. cit.

30. Cf. O Cruzeiro, (12/05/1956, n. 30, p. 68).

31. Cf. O Cruzeiro (12/05/1956, n. 30, p. 68).

32. Cf. Id. (22/09/1962, n. 50, p. 130).

33. Cf. Id. (04/01/1950, n. 3, p. 38). 
34. Ver Luciana Lobo Miranda (2005, p. 30).

35. Ver Anna Cristina Camargo Moraes Figueiredo (1998).

36. Ver Silvia Rosana Modena Martini (2011, p. 22).

37. A introdução desses produtos associa-se a novas tecnologias da casa. O banheiro só seria construído no interior das residências graças às possibilidades oferecidas por vasos sanitários, descargas menos ruidosas, que permitiam a convivência com a eliminação dos dejetos no interior das casas. Ver Francisco Romeu Landi (1993). Dessa mesma forma, o banho apresentaria diferentes modalidades, deslocando-se do banho de bacia ou de banheira, para artefatos como os chuveiros elétricos, especialmente nas áreas urbanas. adotado pelos anúncios, seguindo esse apelo sobre a preservação da saúde. A ameaça dos germes foi uma tônica adotada também por outros anunciantes e produtos.

Em meio a todos esses argumentos do Lifebuoy é necessário destacar aquele discutido neste artigo: a transformação de um sentido, no caso o bom cheiro, num bem material. Agradar ao olfato alheio e não se tornar um incômodo se tornava possível graças a determinadas mercadorias disponíveis na farmácia ou mercado mais próximo.

A veiculação dessas campanhas contra o "C.C." pode ser considerada um marco no combate a algo natural em benefício de um produto artificial, fabricado. Para elas, somente esses produtos seriam capazes de oferecer um bom cheiro, saúde, sucesso profissional e pessoal. Aqueles que os utilizassem estariam em sintonia com o moderno. Além dos produtos, comprava-se uma ideia, uma atitude, um comportamento ${ }^{34}$. Para Anna Cristina Figueiredo 35 , os anúncios são indícios que representam também as aspirações dos próprios consumidores, no caso aqui discutido, de se livrar daquilo considerado um mau odor. Conforme Figueiredo, embora a publicidade busque persuadir o consumidor a adquirir determinado produto, ela parte de aspirações explícitas ou latentes desse mesmo público.

A publicidade esforçou-se para transformar hábitos de higiene. Foi preciso instituir o hábito de consumir esses produtos, insistir nas vantagens adquiridas ao comprá-los. Segundo Silvia Martini, em pesquisa realizada a partir dos arquivos do Instituto Brasileiro de Opinião Pública e Estatística (IBOPE), na década de 1950 ainda era maior o número de pessoas que declaravam não utilizar determinados produtos de uso doméstico, alimentícios e de toucador, entre eles, o desodorante, por exemplo, do que aqueles que declaravam utilizá-los ${ }^{36}$. Apesar disso, os fabricantes investiam em campanhas publicitárias que revertessem esse quadro. A julgar pela presença constante de anunciantes dos mais diferentes produtos, especialmente os de toalete e higiene pessoal, o número de consumidores era crescente. A aquisição do bom cheiro por meio da compra desses produtos foi estimulada pela publicidade, que se empenhou em incrementar as vendas das indústrias químicas, farmacêuticas e de cosméticos. Os produtos eram apresentados como os únicos capazes de cancelar o cheiro de corpo. Estes eram oferecidos como indispensáveis na eliminação do seu cheiro natural. Ação que o banho, sozinho, era incapaz de realizar ${ }^{37}$.

O bom cheiro transformou-se em mercadoria a ser adquirida e uma possibilidade de solucionar o problema do odor desagradável, responsabilizado pela publicidade pelo fracasso e pelo isolamento social. $\bigcirc$ oferecimento de novos produtos por anúncios veiculados em duas revistas de circulação nacional, tornaria a intolerância mais drástica, dada a possibilidade vendida de se exterminar, ou ao menos ocultar o cheiro de corpo.

Para reforçar o desejo pelo bom cheiro, outros fabricantes apelavam para argumentos em defesa da beleza, da maciez da pele, da pureza do produto, 
da economia no orçamento doméstico. llustrações ou fotos apresentavam figuras de mulheres bonitas, felizes e brancas. Algumas atrizes do cinema americano, misses ou estrelas brasileiras dos programas de rádio figuravam em alguns anúncios oferecendo a possibilidade de se atingir o ideal de beleza, de maciez e de juventude, em detrimento da abordagem dos maus odores. Junto a elas, outras mulheres anônimas também figurariam nos anúncios, promovendo a ideia de generalização da beleza ${ }^{38}$.

Nos anos 1950, a maioria dos fabricantes de sabonetes passaria a valorizar em seus anúncios questões estéticas e da valorização da beleza e da maciez da pele, em detrimento do extermínio do cheiro de suor. Essa função foi transferida para os desodorantes.

Com essa valorização da beleza, a utilização de figuras de mulheres bonitas e famosas era uma constante. Mulheres como a Miss Brasil Martha Rocha estrelavam anúncios e também as capas de algumas publicações. No caso de Martha Rocha, num mesmo número da revista $\bigcirc$ Cruzeiro, seu rosto estampou a capa e o anúncio da Gessy. Atrizes como Gracy Kelly, Gina Lollobrigida, entre outras, ajudaram a compor aquilo denominado por Classen, Howes e Synnott como "mundo da fantasia" criado pela indústria cinematográfica de Hollywood ${ }^{39}$. A linguagem do cinema acabava valorizando apenas os sentidos da visão e da audição. Essas representações inodoras acabaram por fomentar os esforços em torno de um corpo desodorizado. Segundo esses autores, no século XX, esse era o ideal propagado na cultura ocidental: o de uma sociedade desodorizada ${ }^{40}$.

Ao mesmo tempo, junto a essas estrelas de cinema ou misses, figurariam nesses anúncios mulheres anônimas que expressavam sua sensualidade descontraída, atitude, até então, pouco usual. Essa difusão da beleza anônima é considerada um traço característico das décadas de 1950-1960, segundo Vigarello ${ }^{41}$. Esse foi o período da valorização da beleza "de todos", em que a beleza dos idosos, dos humildes, dos gêneros seria revista. $\bigcirc$ corpo passou a ser considerado como "o objeto de consumo mais belo"42. No anúncio do desodorante Odorono (Figura 2), o foco da fotografia é no rosto da modelo (anônima) que aparece com os lábios entreabertos, perguntando-se: "Eu?", como se questionasse se estava com mau cheiro nas axilas. Embora o anúncio seja de um desodorante, a parte do corpo que se destacou foi os lábios entreabertos, numa atitude de sensualidade - quase - ingênua.

Além da desodorização, era preciso apresentar-se jovem, bonita, com a pele perfumada e macia. Diferentemente do combate ao "cheiro de corpo", apenas uma parte do corpo era contemplada: o rosto. Há um certo silêncio em torno da questão dos odores do corpo como um todo. Este passou a ser dividido em zonas de perigo olfativo. E para cada um desses lugares havia uma solução industrializada, um produto específico para cada problema.

Atrelar os produtos a essas figuras e veiculálos por meio de anúncios publicitários remetem à questão de que o bom cheiro representava um bom negócio. Além do desejo de se manter limpo, higienizado e livre de seus odores
38. Ver Georges Vigarello (2005).

39. Cf. Constance Classen; David Howes e Anthony Synnott (2002, p. 175).

40. Idib., loc.cit.

41. Ver Georges Vigarello (2005).

42. Cf. Georges Vigarello (2005, p. 254). 


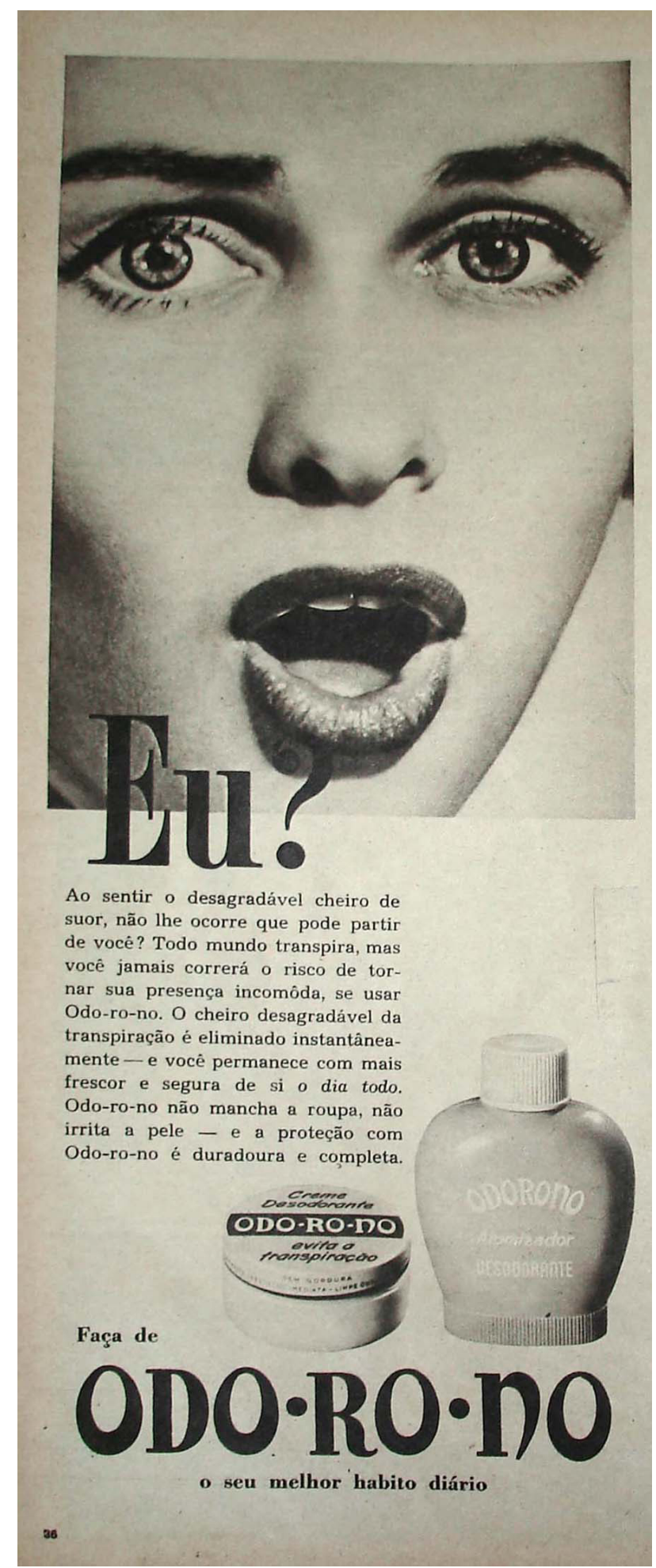

Figura 2 - Anúncio do desodorante Odorono. O Cruzeiro, 30/01/1960, n. 16, p. 36. Acervo Biblioteca Nacional - Rio de Janeiro e Acervo Estado de Minas/Revista $\bigcirc$ Cruzeiro - Belo Horizonte. 
naturais, havia, ainda conforme Smith, um desejo reprimido de gastar com o embelezamento. A austeridade do período da Segunda Guerra acabara gerando a necessidade de se investir em algo que em nada lembrasse os tempos de escassez do conflito. No pós-guerra, esse "glamour" podia ser adquirido no mercado, por meio da aquisição de produtos que prometiam beleza e juventude ${ }^{43}$.

Dessa forma, estar livre do cê-cê traduzia-se na compra de uma mercadoria, e movimentava o comércio e a indústria. $\bigcirc$ cheiro tornava-se uma peça no circuito capitalista. E o diferencial dessa nova era do consumo relacionava-se à disponibilidade de produtos fabricados e distribuídos numa escala de massa e à publicidade para promover seu uso. Essa nova forma de penetração capitalista, segundo Classen, Howes e Synnott, foi possível graças ao desenvolvimento de certas práticas publicitárias, com especial atenção para a utilização do drama social${ }^{44}$.

$\bigcirc$ combate ao "cheiro de corpo" desmembrava-se. $\bigcirc$ "CC" localizavase nas axilas, na boca e até mesmo nas roupas. Para qualquer um desses problemas, o mercado oferecia uma solução. $\bigcirc$ bom cheiro estava disponível para aqueles que o quisessem comprar, ingressando no circuito de mercado como um produto e, na cultura material, como um atributo obrigatório na obtenção de sucesso pessoal e profissional.

Conforme Suellen Hoy, nos Estados Unidos da década de 1920, o objetivo do "negócio da limpeza" era produzir suprimentos de sabonete em abundância, para que tanto "ricos quanto pobres" adquirissem os produtos. Para que essas compras se efetivassem, os fabricantes decidiram educar quanto ao uso desses produtos, na mesma medida em que os anunciava. Os fabricantes de sabões e outros produtos de limpeza passaram a liderar movimentos em prol da higiene. Num lançamento de uma dessas campanhas, o presidente da Associação Americana de Produtores de Sabões e Glicerinados, Sidney M. Colgate, convocou seus convidados, entre eles oficiais de saúde, educadores, publicitários, líderes de organizações sociais e representantes de clubes femininos a cooperarem na promoção da limpeza. Além de representar um bom negócio, a limpeza era também importante na valorização da saúde e do bem-estar social do país. Essa busca pela limpeza alcançaria seu ápice nos anos subsequentes à Segunda Guerra Mundial45.

A situação no Brasil era semelhante, pelo menos nos centros urbanos. Havia nos anos 1950 um pesado investimento em propaganda e também na defesa da higiene, da saúde e, também, da beleza. Entretanto havia uma diferença entre americanos e brasileiros. Conforme Hoy, era preciso educar os americanos (imigrantes e nativos) a utilizar o sabonete. A autora aponta a preocupação dos fabricantes de que a nação não usava sabonete o suficiente. "Os fabricantes estavam genuinamente preocupados acerca da 'cultura desmanzelada' do americano" em relação à higiene ${ }^{46}$. Já o Brasil era um povo considerado "essencialmente limpo" 47 . $\bigcirc$ esforço centrava-se na ação de substituir os preparados caseiros, como o sabão de cinzas, por exemplo, por produtos industrializados.
43. Cf. Virginia Smith (2007, p. 330).

44. Ver Constance Classen; David Howes e Anthony Synnott (2002, p. 182).

45. Cf. Suellen Hoy (1995, p. $142 ; 152)$.

46. Cf. Ibid. (p. 141).

47. Cf. Rodolfo Lima Martensen (1983, p. 233). 
48. Ver Georges Vigarello (1996).

49. Cf. Constance Classen; David Howes e Anthony Synnott (2002, p. 180)

50. Cf. Ana Paula Goulart Ribeiro (2007, p. 182).

51. Ibid., loc. cit.

52. Cf. Constance Classen; David Howes e Anthony Synnott, loc. cit.

53. Cf. Ibid. (p. 180-181)
A estratégia se concentraria na manutenção e prolongamento da sensação de limpeza proporcionada pelo banho. Sabonetes, como o Lifebuoy por exemplo, e desodorantes teriam a missão de eliminar o "cheiro de corpo". Enquanto isso, sabonetes que valorizavam a essência e os perfumes, propriamente ditos, investiam numa "nova identidade olfativa", valorizando as essências, o momento do banho como de relaxamento. O banho, conforme Georges Vigarello, possuía outras representações, como um momento de prazer e até mesmo de encontros sociais ${ }^{48}$. De maneira análoga, o banho em meados do século XX apresentava outras características além da limpeza. Representava também um momento de relaxamento e, principalmente, de embelezamento.

Classen, Howes e Synnott apontam que a publicidade oferecia mais do que o uso prático de um produto. Vendia-se uma imagem e um estilo de vida. Esses autores consideram que esse fenômeno de "image marketing" foi mais explícito nas propagandas de desodorantes e perfumes: "O controle dos odores do corpo é a maior preocupação dos ocidentais, que fizeram da indústria do desodorante e da toalete um negócio de bilhões de dólares" 49 .

Ana Paula Goulart Ribeiro destaca que na primeira metade da década de 1950 os maiores anunciantes "eram de artigos de consumo diário, como produtos de higiene, medicamentos, cigarros e bebidas". Panorama que mudou completamente, segundo a autora, na segunda metade da década, com o crescimento da indústria automobilística ${ }^{50}$. Segundo dados coletados por Ribeiro no Anuário de Publicidade, entre os maiores anunciantes de 1953 figuravam fabricantes de produtos de higiene pessoal, perfumaria e afins, tais como: Cia. Industrial Gessy (que destinavam 27 milhões de cruzeiros à publicidade); The Sidney Ross Company (25 milhões); Irmãos Lever (20 milhões); Johnson \& Johnson (1 3,5 milhões); Gillette Safety Co. of Brazil (1 3 milhões) e Colgate-Palmolive Peet Co. $(12 \text { milhões })^{51}$. Apesar da força da indústria automobilística na segunda metade dos anos 1950, esses fabricantes ainda continuaram entre os maiores anunciantes da imprensa brasileira.

Para Hoy, no pós-guerra houve uma "revolução dos bens-de consumo", que oferecia uma variedade de sabões, desodorantes, detergentes, acessórios para banheiros, entre outros. Muitos deles adotavam a mesma ideia dos sabonetes, o combate ao cheiro de corpo, especificamente, e aos odores fétidos de maneira geral. Entretanto, Classen, Howes e Synnott alegam que a valorização das fragrâncias estava presente em outros produtos, tais como detergentes, tintas de parede, e uma "vasta gama de produtos envoltos na aura olfativa" ${ }^{2}$. Ainda conforme esses autores, essa adição de aromas aos produtos conferia um significado de "refrescância" e de efetividade. Essa aromatização em nada interferia no desempenho: "Esse 'aroma do produto' [aroma of the commodity] (...) era considerado pelas pesquisas de mercado como crucial para que o consumidor percebesse e considerasse o produto como desejável e com o mérito de ser adquirido" 53 .

Corbin enumera outras vias do corpo que também mereciam atenção e cuidados quanto aos seus potenciais maus odores. Além das glândulas sudoríparas, 
ele contabiliza seis pontos ou "emunctórios corporais" que se distinguiam pelo forte odor: "a parte cabeluda da cabeça, as axilas, os intestinos, a bexiga, as vias espermáticas, as separações dos artelhos" 54 .

Ao analisar as relações entre questões religiosas e a representação da sujeira e da pureza nos ritos, Mary Douglas também enumera os orifícios do corpo como símbolos de pontos vulneráveis e prováveis fontes do mau cheiro ${ }^{55}$. Tanto Douglas quanto Corbin, ao analisarem diferentes épocas ou situações, afirmam que os odores emanados dos corpos começariam a partir do século XIX a serem marcados pelo selo da estranheza. Douglas, ao discutir a representação da higiene e da saúde, da pureza e da impureza nas religiões primitivas e nas grandes religiões, aponta que em algumas religiões a importância do incenso se liga menos ao simbolismo do que ao fato de que o perfume torna "tolerável o odor de pessoas mal lavadas" 56 .

A vasta gama de mercadorias também estava disponível no mercado brasileiro. Até mesmo as tintas para parede defendiam a proteção do olfato, ao dizer que não deixavam nenhum cheiro no ambiente. Essa era uma das estratégias para que o produto alcançasse o mérito destacado por Classen, Howes e Synnott de fazer parte do cotidiano do brasileiro da década de 1950.

Sociabilidade ameaçada: o mau cheiro da boca e das axilas

Dada a variedade de produtos, o corpo seria dividido em meados do século XX em partes potencialmente fétidas, tais como a boca e as axilas. $\bigcirc$ "CC" acabaria se deslocando do corpo como um todo para se instalar especificamente nesses emunctórios. Para cada problema, um produto diferente.

O mau hálito, junto com o temido "C.C.", era uma das maiores ameaças para o convívio social. Enfatizava-se o afastamento causado por tal problema e o perigo do isolamento. As palavras proferidas deveriam emanar de uma boca com "bom gôsto": "Se Você diz coisas alegres e ninguém sorri, cuidado! É que suas palavras não têm bom gôsto! A diferença é Mentasol. Agora sim! suas palavras têm bom gôsto! ... Mentasol (...) elimina todos os odôres da bôca!"(Figura 3) ${ }^{57}$.

Eliminar todos os "odôres da boca" era equivalente a ocultar uma das emanações do "cheiro de corpo". O aconselhamento para o uso de produtos que exterminassem 0 mau hálito apelava para 0 drama social ${ }^{58}$. $\bigcirc$ mau hálito era apresentado como um dos causadores da solidão, de desavenças, de confusões, de fracassos na vida pessoal e profissional. Para tanto, alertava-se:

Não perca sua oportunidade... não deixe que o mau hálito interrompa seu êxito pessoal e comercial... (...) Confie em Kolynos e assegure seu futuro. Kolynos é o dentifrício mais popular porque sua espuma refrescante, eficaz e abundante combate as cáries, perfuma o hálito e rende muito mais! 59

mau hálito poderia ser considerado como um dos mais graves e ameaçadores problemas ao convívio social. Com esse problema, a sociabilidade
54. Cf. Alain Corbin (1987, p. 53).

55. Ver Mary Douglas (1991, p. 145).

56. Cf. Mary Douglas (1991, p. 43).

57. Cf. O Cruzeiro $(28 / 11 / 1959$, n. 7 , p. 57 , itálico nosso).

58. Ver Constance Classen; David Howes e Anthony Synnott (2002).

59. Cf. O Cruzeiro, $(04 / 10 / 1952$, n. 51 , p. 46 , itálico nosso). 
ficaria comprometida. $\bigcirc$ "CC" e o mau hálito juntos condenariam o indivíduo ao isolamento. Nos anúncios aqui selecionados, destaca-se essa ameaça. $\bigcirc$ mau hálito seria responsável pelo fracasso profissional para os homens e pela solidão das mulheres. Quem se casaria com alguém com mau hálito? Era preciso substituir o gosto da cebola, como apresentado no anúncio do Mentasol, pelo aroma das

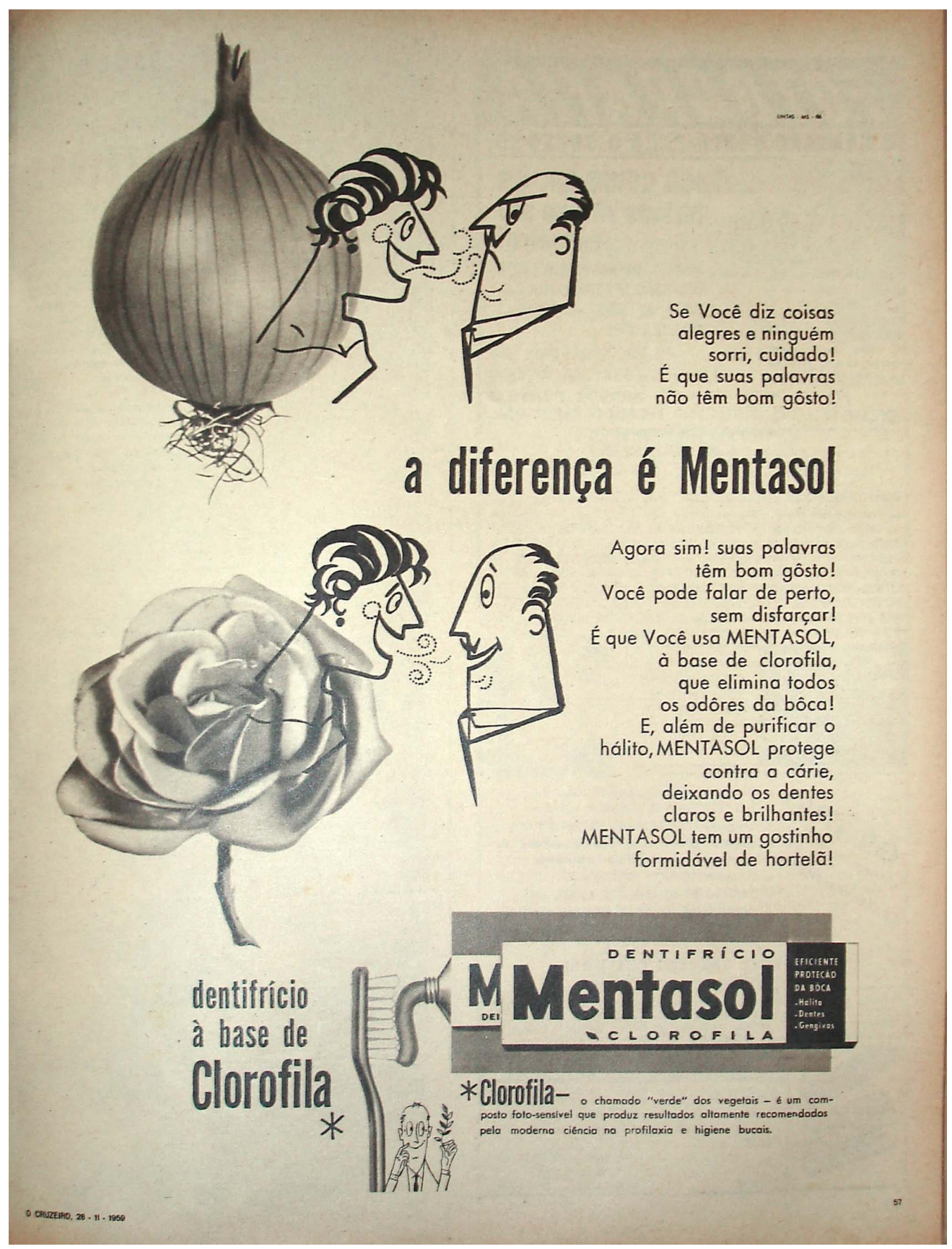

Figura 3 - Anúncio dentrifrício Mentasol. O Cruzeiro, 28/1 1/1959, n. 7, p. 57. Acervo Biblioteca Nacional - Rio de Janeiro e Acervo Estado de Minas/Revista $O$ Cruzeiro - Belo Horizonte. 
rosas. Somente assim o indivíduo passaria a ocupar um lugar de destaque na sociedade.

combate ao mau hálito, assim como a campanha de combate ao "CC", também criou termos para denominar esse problema. Classen, Howes e Synnott atribuem à campanha publicitária do "enxaguatório" bucal Listerine a autoria do termo "halitose". Para esses autores, essa designação representou um "dos maiores avanços na prática publicitária"60. Isso porque, ao criar uma denominação para o mau hálito, os publicitários puderam falar abertamente sobre algo que antes, supostamente, ninguém falara "a fonética científica do termo, exumado de um velho boletim médico, ajudava a colocar a questão do mau hálito sobre condições médicas" "bl. Sob os auspícios da medicina, o mau hálito se tornaria algo que poderia e deveria ser tratado ${ }^{62}$.

Ao apropriar-se da autoridade da medicina, alguns produtos ofereciamse para combater não somente os possíveis maus odores expelidos pela boca, mas também para protegê-la e desinfetá-la para que algumas doenças fossem evitadas. Ou seja: era necessário proteger a saúde e manter a higiene da boca contra os maus odores. $\bigcirc$ bom cheiro e a saúde poderiam ser comprados e transformados em bens de consumo:

$90 \%$ de todas doenças penetram pela boca. Você sabia que a boca é um campo ideal para a vida de germes patogênicos? E que, ao respirar, você ingere milhões de micróbios que, se não forem combatidos, podem contaminar seu organismo? Proteja-se contra êste perigo! Elimine as bactérias causadoras das cáries dentais, das infecções bucais e do mau hálito, usando Odorans. Odorans é recomendado pelos melhores médicos e dentistas ${ }^{63}$.

Havia, entretanto, outro "mau hálito" a ser combatido: o dos nossos braços. A solução estava num novo produto: o desodorante. Ao contar a história de sua marca, a Unilever relatava que o produto fora inventado nos anos 1910 nos Estados Unidos. Mas só se popularizou depois da Segunda Guerra, quando houve um crescimento da indústria da higiene e beleza no Hemisfério Norte. No Brasil, como apontado por Martensen, o desodorante não estava acessível a todos $^{64}$. Havia uma desconfiança em relação à eficácia do desodorante e aos efeitos que poderia causar à saúde. $\bigcirc$ suor era considerado algo natural, que deveria ser expelido pelo corpo. $\bigcirc$ conselho era utilizar produtos que não obstruíssem os poros e mantivessem a circulação do suor e ao mesmo tempo eliminassem o mau cheiro provocado pelas bactérias localizadas nas axilas. Esses temores eram abordados sutilmente pelos fabricantes: "D-Ten - desodorante perfeito: não prejudica a saúde, não mancha a roupa, não irrita a pele, deliciosamente perfumado"65.

Para outros, a resistência ao desodorante era algo relacionado ao hábito de tomar banho diariamente. Havia uma tentativa de se aliar o banho ao desodorante. Este seria considerado um aliado ou um complemento do primeiro: "Interessante: as pessoas que tomam banho todos os dias são as que mais usam Desodorante 1010"66. Essa frase indicava que nem todos tomavam banho
60. Cf. Constance Classen; David Howes e Anthony Synnott (2002, p. 183).

61. Ibid., loc. cit.

62. Ibid. (p. 184).

63. Cf. O Cruzeiro (14/06/1952, n. 35, p. 28).

64. Ver Rodolfo Lima Martensen (1983).

65. Cf. Manchete, (26/09/1959, n. 388, p. 37).

66. Cf. O Cruzeiro (14/07/1962, n. 40, p. 51). 
67. Ibid., loc. cit.

68. Cf. Henrique Pongetti (1958, p. 31).

69. Ibid., loc. cit.

70. Ibid. loc. cit.

71. Ibid. loc. cit.

72. Ver Constance Classen; David Howes e Anthony Synnott (2002, p. 187).

73. Cf. O Cruzeiro, (30/01/1960, n. 16 , p. 36 , itálico do autor). diariamente. $\bigcirc$ esforço era de convencer o consumidor a utilizar o desodorante como um complemento do banho. Argumentava-se que quem possuía esse hábito e aplicava o desdorante eram pessoas "inteligentes" e "evoluídas":

[Elas] Sabem como prolongar, pelo dia inteiro, a sensação refrescante do banho. Têm consciência da necessidade de proteger-se a si (e aos outros) dos odôres causados pela transpiração - que é uma coisa absolutamente normal num país de clima quente como o nosso. (...). Contém um moderno antisséptico: elimina completamente a ação das bactérias causadoras do odor ${ }^{67}$.

O discurso era semelhante ao do sabonete Lifebuoy: o temor de que o mau cheiro do próprio corpo representasse um incômodo para si mesmo e, principalmente, para o outro. Esse temor não era uma exclusividade dos anunciantes e apenas uma tentativa de vender o produto. Os valores subjetivos dessas campanhas publicitárias baseavam-se em ameaças olfativas que se expressavam também em artigos publicados nas revistas, como o escrito pelo jornalista e exdiretor da revista Manchete, Henrique Pongetti.

No artigo intitulado As raças e o olfato, Pongetti questionava-se sobre qual era o odor do brasileiro. O articulista afirmava que "nossa gente é [era] das mais limpas da humanidade", adepta do banho diário. Mas destacava que somente isso não era suficiente para eliminar o bodum das axilas. Pongetti cita o sabonete Lifebuoy e sua "feliz abreviação" para o problema do "C.C.". Porém salientava que o sabonete, sozinho, não resolvia o problema dos "povos tropicais ou não" de exalar "aquêle nosso cheiro típico, axilar" que "permanecia no ar como um rastro olfativo, misto de cebola com barata, acre, penetrante, pegajoso"68.

Para resolver esse problema, segundo Pongetti, somente o uso do desodorante. Ele falava dos Estados Unidos, onde sua utilização era corriqueira, como o uso da pasta de dentes. A eficácia do produto permitia que algumas "louras dinâmicas" adiassem "um banho por causa dos afazeres ou da preguiça, sem receio de serem denunciadas pelos seus íntimos eflúvios"69. Já a resistência aqui se vinculava ao fato de que o brasileiro era "positivamente amigo da água e do sabão"70. Pongetti aspirava ao lançamento de um desodorante popular que seria adotado imediatamente por todas as classes sociais. $\bigcirc$ desodorante seria capaz de alertar "contra a parte mais perigosa e mais esquecida do nosso corpo - os braços, os braços próximos de todos os olfatos, em contínua agitação como os turíbulos procissionais; diretos como vaporizadores de essências" 71 .

Classen, Howes e Synnott apontam que o desodorante possuía também a função de evitar a rejeição social. A questão emergente, segundo os autores, era: como conseguir a aprovação social ${ }^{72}$.

Eu? Ao sentir o desagradável cheiro de suor, não the ocorre que pode partir de você? Todo mundo transpira, mas você jamais correrá o risco de tornar sua presença incômoda, se usar Odo-ro-no. O cheiro desagradável da transpiração é eliminado instantâneamente - e você permanece com mais frescor e segura de si o dia todo (Figura 2) 73. $^{3}$. 
Para Pongetti, havia duas "campanhas graves" a se realizar no Brasil: "a da alfabetização intensiva e a da desodoração geral"74.

Nós vemos nas favelas mulheres subindo com latas de água na cabeça em trilhas longas e estóicas como as das formigas: também elas se lavam, mas suas axilas lavadas não nos deixam acreditar na sua espartana higiene. As negras do Harlem saracoteiam a noite tôda em volta do seu nariz, no bar com 'show', e o seu perfume não se deturpa: mas, a um gesto mais amplo dos seus braços, você vê, entre o cabelo raspado das axilas, a brancura do creme mágico. O nosso índio amazônico vive se banhando, e êsse amor à água está no sangue da gente de Belém e de Manaus. Muita água do rio inesgotável se despeja pelos chuveiros das casas civilizadas em vários banhos diários pedidos pelo suor e pela quentura $^{75}$

Ao mesmo tempo em que afirma que nada substituiria o desodorante, o autor apontava para o poder do banho de cheiro e a utilização de ervas aromáticas oriundas da região amazônica:

Mas o que é banho-de-cheiro, o que é aquêle costume de esconder nos cabelos ou em escapulários raízes e favas aromáticas, senão o instinto do desodorante, a sua intuição? Muitas vêzes passei pelo Ver-o-Pêso e me detive diante das garrafas de ervas cheirosas, das bancas de raízes de pós estonteantes. Aquêles cheiros naturais se impregnam no corpo e perfumam tôdas as suas emanações como se a pele respirasse essências. Minha querida e inteligentíssima amiga Eneida tem no seu novo e triunfante livro Aruanda um capítulo sôbre o 'banho-de-cheiro' ou 'banho da felicidade' tomado em água onde se ferveu manjerona, bergamota, catinga-de-mulata, pataqueira, priprioca, cipó-catinga, arruda, baunilha, cipoíra etc ${ }^{76}$.

Apesar de todos esses esforços para eliminar os maus odores das axilas, Pongetti afirmava: "Somos um povo bem banhado e mal desodorado"77. No artigo, o autor apontava a obssessão em torno da eliminação do "cheiro de corpo". Essa busca não partia somente dos indivíduos, mas, principalmente, dos fabricantes, que transformaram tal ideal de desodorização em mercadorias. Pongetti admiravase com o lançamento de "uma grande novidade", anunciada pelos jornais como se fosse "notícia redacional do dia":

mediante um tratamento químico especial, os tecidos de sua fabricação atuariam sôbre o corpo do consumidor como um completo desodorante. $\bigcirc$ tecido [...] ganhava uma faculdade milagrosa: defender-nos das emanações do suor que nestas terras quentes traem criaturas de higiene exemplar, escravas legítimas da água e do sabão ${ }^{78}$.

Pongetti falava dos produtos "sanitizados". $\bigcirc$ jersey sanitizado"79 era um tecido que dizia ter passado por um "processo bacteriológico" que impedia "a formação de bactérias e outros microorganismos. Evita[va] os odores da transpiração e prolonga[va] a vida dos tecidos pela destruição dos germens que o atacam. [...]. É a maior conquista no campo da higiene nos últimos 25 anos!"80.
74. Cf. Henrique Pongetti (1958, itálico nosso).

75. Ibid. (p. 31).

76. Cf. Henrique Pongetti (1958, p. 31).

77. Ibid., loc. cit.

78. Ibid., loc. cit.

79. O jersey Nailotex era produzido a partir do náilon. Essa fibra sintética seria considerada uma revolução na indústria têxtil. Segundo Mário Donato, o náilon foi saudado como "a mais importante descoberta química desde o processo de Fritz Haber para extrair nitrogênio do ar". Descoberta em 1929, nos laboratórios da Du Pont, pelos químicos Wallce Hume Carothers e seu auxiliar, John Hill, a fibra só começou a ser vendida às fábricas de meias em maio de 1940. Cf. Mário Donato (1972, p. 46)

80. Cf. Manchete $(19 / 10 / 1957$, n. 287, p. 31$)$ 
81. Cf. Henrique Pongetti (1958, p. 31).

82. Cf. O Cruzeiro (14/07/1962, n. 40, p. 20).
Nesse artigo publicado na revista Manchete, em 1957, Pongetti sintetizou num único texto muitos dos temores que permeavam o cotidiano brasileiro no que se referia ao perigo dos maus odores, especialmente aquele exalado das axilas. Há no texło uma apologia ao consumo de desodorante dos norte-americanos, que já tinham adotado o produto como parte integrante de seus hábitos de higiene e de limpeza. Para além da questão do consumo, utilizar o produto era sinônimo também de estar ligado ao que acontecia num país que servia de modelo de hábitos e costumes. Concomitantemente a essa apologia aos americanos, Pongetti abordava de maneira um tanto quanto poética, o costume de utilizar os preparados naturais oriundos de uma flora rica em aromas: "(...) beijar a axila de uma mameluca é o mesmo que beijar o aroma da 'dama da noite' ou outra perdição do nosso olfato" ${ }^{\prime 81}$. O ponto desafiador era converter esse hábito de se manter livre dos odores em um processo de substituição das ervas aromáticas por produtos industrializados. Pongetti acabou apontando para os benefícios dos produtos industrializados ao falar do tecido que combatia os maus odores e a proliferação dos germes, evitando assim dois problemas simultaneamente: o do "cheiro de corpo" e o das doenças. Estas, a exemplo do mau cheiro do corpo, encontravam sua eliminação no uso de medicamentos, como a penicilina, por exemplo, e, também em produtos que prometiam exterminar os germes, as bactérias, entre outras ameaças. $\bigcirc$ processo de "sanitização" - algo como uma espécie de esterilização química - dizia-se popular e presente em diversos artefatos.

Quatro anos mais tarde, em 1962, outro anúncio demonstrava que o processo de eliminação dos odores estendera-se para outros produtos, tais como calçados, brinquedos, plásticos, "pràticamente tudo que V. usa diàriamente". A ênfase ao combate aos odores do corpo continuava presente: "Os produtos sanitizados não 'pegam' os maus odores da transpiração. As roupas, as meias e os calçados tratados com SANITIZED estão sempre frescos e agradàvelmente confortáveis" 82 .

Apesar dessa vasta gama de produtos que prometiam eliminar o "cheiro de corpo", o banho continuava a ser o maior aliado do brasileiro nesse combate. Os demais produtos vinham para prolongar o efeito de frescor, bem-estar e bom cheiro. $\bigcirc$ desafio de se instituir novos hábitos de consumo de produtos de higiene modernos persistia.

No Brasil de meados do século XX, a questão não era a falta de banho, mas o desejo mercadológico de inserir no cotidiano da higiene pessoal produtos industrializados que prometiam eliminar o problema do "cheiro de corpo" - o cê-cê.

\section{Considerações finais}

A relação entre consumo e mudanças de hábitos dos brasileiros das áreas urbanas do Brasil dos anos 1940 a 1960 estava além da simples aquisição de um produto. A diversificada gama de mercadorias oferecidas nesse período traduzia a aspiração de modernidade, de consolidação do parque industrial e também do fortalecimento de um mercado de bens de consumo. Corresponde a 
um período democrático inaugurado com o fim do Estado Novo e encerrado com o golpe civil/militar de 1964.

Nesse processo de consumo de novos produtos celebrou-se a substituição do odor natural pelo cheiro artificial, pelos aromas fabricados. $\bigcirc$ uso da palavra "odor" e "cheiro" tem aqui uma conotação especial. $\bigcirc$ odor relacionava-se ao fétido e a palavra "cheiro" e "aroma" àquilo considerado agradável. No caso específico do Brasil, nesses vinte anos, defendia-se o cancelamento do cheiro de corpo em prol da adoção e, principalmente, da compra de produtos que prometiam exterminar qualquer mau odor - especialmente, o cheiro de corpo. Exalar seu odor natural, de suor, era sinônimo de atraso, de algo ultrapassado. A aspiração pela modernidade deveria ser exalada até pelos poros.

A adoção desses novos produtos e de uma nova maneira de viver mais higiênica e mais saudável - não aconteceu de maneira automática. Era preciso educar o olfato para que odores emanados pelo corpo fossem marcados pelo "selo da estranheza"83. Essa tarefa coube à publicidade. Nesse mesmo contexto de desenvolvimento, a imprensa do período, entenda-se publicidade e jornalismo, também experimentou sua fase de crescimento e de modernização. $\bigcirc$ investimento em impressoras e máquinas capazes de imprimir com maior rapidez e melhor qualidade acabaria por fomentar as vendas dos espaços publicitários. Revistas de circulação semanal e nacional como $\bigcirc$ Cruzeiro e Manchete teriam seus espaços valorizados e disputados pelos anunciantes. Estes se utilizavam dos serviços de agências norte-americanas aqui presentes e de outras agências publicitárias para veicular suas campanhas para todo o país. A influência dessas agências se faria presente nos anúncios que apresentavam, predominantemente, mulheres caucasianas em suas peças publicitárias.

Havia uma consonância entre as aspirações do Brasil a se tornar moderno e desenvolvido, dos fabricantes de bens de consumo a se estabelecer e da publicidade a veicular e fomentar a venda desses produtos. A missão era convencer a população - a começar com os leitores dessas revistas - a adotar esses novos produtos que prometiam solucionar todos os problemas. Especialmente o problema dos maus odores corporais. Para tanto aquilo que era natural, como o cheiro de corpo, recebeu um rótulo - "CC" - e passou a ser considerado como algo repugnante, uma patologia que poderia ser tratada e curada com a aquisição de um sabonete. Esse processo foi tão bem-sucedido que o cê-cê foi dicionarizado.

Essa mudança foi material e cultural. Um episódio em um processo mais longo de construção de uma nova sensibilidade moderna, que classificou os odores de acordo com lugares, grupos sociais e partes do corpo, em uma escala que variava entre a repulsa e a valorização. A novidade desse período posterior à Segunda Guerra Mundial, em particular no Brasil das décadas de 1940 e 1950, foi a aliança dessa aspiração pelo bom cheiro artificial e fabricado associada à industrialização, aos processos de urbanização, à modernização da imprensa e da publicidade e, consequentemente, à possibilidade de adquirir saúde embalada em novos produtos, em uma escala de difusão maior do que nos períodos anteriores. 


\section{REFERÊNCIAS}

CLASSEN, Constance; HOWES, David; SYNNOTT, Anthony. Aroma: the Cultural History of Smell. Londres: Routledge, 2002.

COELHO, Edeson Ernesto. Edeson Ernesto Coelho: depoimento [2004]. Rio de Janeiro: CPDOC, ABP - Associação Brasileira de Propaganda, Souza Cruz, 2005. Disponível em <www.fgv.br/ cpdoc/historal/arq/Entrevista1213.pdf>. Acesso em 16 nov. 2012.

CORBIN, Alain. Saberes e odores: o olfato e o imaginário nos séculos dezoito e dezenove. São Paulo: Companhia das Letras, 1987.

DONATO, Mário. O mundo do plástico: o plástico na história, o plástico no mundo, o plástico no Brasil. São Paulo: Goyana, 1972.

DOUGLAS, Mary. Pureza e perigo: ensaio sobre as noções de poluição e tabu. Lisboa: Edições 70, 1991.

FIGUEIREDO, Anna Cristina Camargo M. Liberdade é uma calça velha, azul e desbotada: publicidade, cultura de consumo e comportamento político no Brasil (1954-1964). São Paulo: Hucitec, 1998.

HOY, Suellen. Chasing Dirt: the American Pursuit of Cleanliness. Nova York: Oxford University Press, 1995.

LANDI, Francisco Romeu. A evolução histórica das instalações hidráulicas. Boletim Técnico da Escola Politécnica da USP - EPUSP, São Paulo, 1993. Disponível em <http://www.pcc.usp.br/files/ text/publications/BT_00100.pdf>.

MARTENSEN, Rodolfo Lima. O desafio de quatro santos: memórias. São Paulo: LR Editores, 1983.

MARTINI, Silvia Rosana Modena. O IBOPE, a opinião pública e o senso comum dos anos 1950: hábitos, preferências, comportamentos e valores dos moradores dos grandes centros urbanos (Rio de Janeiro e São Paulo). Tese (Doutorado) - Universidade Estadual de Campinas, Instituto de Filosofia e Ciências Humanas, Campinas, 2011.

MCGOVERN, Charles F. Sold American: Consumption and Citizenship, 1890-1945. Chapel Hill: The University of North Carolina Press, 2006.

MILLER, Daniel. Consumption and Commodities. Annual Review of Anthropology, Palo Alto, p. 141-161, 1995.

MIRANDA, Luciana Lobo. Subjetividade: a (des)construção de um conceito. In: SOUZA, S. J. (Org.). Subjetividade em questão: a infância como crítica da cultura. 2 ed. Rio de Janeiro: 7 Letras, 2005. p. 29-46.

PINHEIRO, Paulo César; GIORDAN, Marcelo. O preparo do sabão de cinzas em Minas Gerais, Brasil: do status de etnociência à sua mediação para a sala de aula utilizando um sistema hipermídia etnográfico. Investigações em Ensino de Ciências, Porto Alegre, v. 15, n. 2, p. 355-383, 2010. 
PONGETTI, Henrique. As raças e o olfato. Manchete, Rio de Janeiro, n. 304, p. 31, 15 fev. 1958.

RIBEIRO, Ana Paula Goulart. Imprensa e bistória no Rio de Janeiro dos anos 1950. Rio de Janeiro: E-papers, 2007.

SMITH, Virginia. Clean: a History of Personal Hygiene and Purity. Nova York: Oxford University Press, 2008.

SIMÕES, Roberto. Do pregão ao jingle. In: BRANCO, Renato Castelo; MARTENSEN, Rodolfo Lima e REIS, Fernando (Coord.). História da propaganda no Brasil. São Paulo: T. A. Queiroz, 1990. p. 171-202. (Coroa vermelha, Estudos brasileiros, v. 21).

SODRÉ, Nélson Werneck. História da imprensa no Brasil. 2 ed. Rio de Janeiro: Edições do Graal, 1977.

STEARNS, Peter N. Consumerism in World History: the Global Transformation of Desire. 2 ed. Londres, Nova York: Routledge, 2006.

TOMES, Nancy. The Gospel of Germs: Men, Women, and the Microbe in American Life. Massachusetts: Harvard University Press, 1999.

VIGARELLO, Georges. O limpo e o sujo: Uma história da higiene corporal. São Paulo: Martins Fontes, 1996.

. História da beleza: O corpo e a arte de embelezar: da Renascença até os nossos dias. Lisboa: Editorial Teorema, 2005.

. Le sentiment de soi: histoire de la perception du corps (XVIe.-XXe sièle). Paris: Éditions du Seuil, 2014.

Artigo apresentado em 30/10/2014. Aprovado em 13/04/2015. 